\title{
A Cross-sectional Online Survey on Public Attitudes towards Wearing Face Masks and Washing Hands to Prevent the Spread of COVID-19 in Indonesia
}

\author{
Hotma Rumahorbo $^{1 *(\mathbb{D}) \text {, Priyanto Priyanto }}{ }^{2}$ (D) Atin Karjatin ${ }^{3}$ iD \\ ${ }^{1}$ Nursing Program, Bandung Health Polytechnic, Jawa Barat, Indonesia; ${ }^{2}$ Indramayu State Polytechnic, Jawa Barat, Indonesia; \\ ${ }^{3}$ Health Promotion Program, Bandung Health Polytechnic, Jawa Barat, Indonesia
}

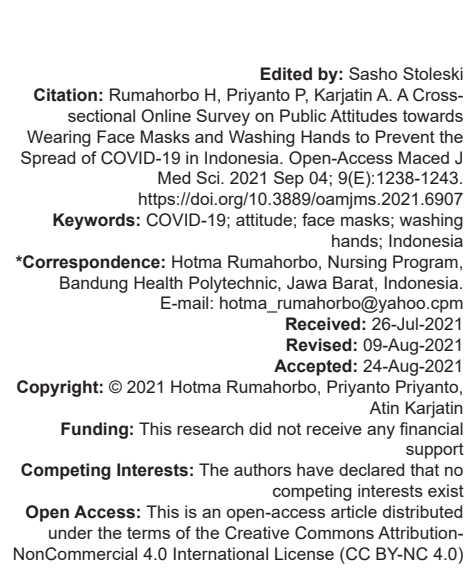

\section{Introduction}

After the first case in Wuhan, China, SARSCov-2 virus infection and named Corona (Covid-19) was identified in the late December 2019 [1]. The has virus spread massively to several countries outside China, including Indonesia.

In Indonesia, the first case was found on March 2, 2020 [2], and since then, there has been a significant increase in the number of cases. On the $2^{\text {nd }}$ week of June 2020 , there were 41,431 cases with 2276 deaths, and it was the highest death number in Southeast Asia [3]. Up to date, there have been many countries in the world including Indonesia, facing a new wave of cases and deaths. The highest COVID19 cases are suffered by age group of 31-45 years old, followed by age group of 19-30 years old. However, the highest deaths are found in people aged $>46$. The highest infections are found in women but the highest deaths are in men. Comorbidity such as hypertension, diabetes mellitus, and heart disease, is identified as inhibition of healing [3].
COVID-19 infection is a virus infection with a high transmission rate. It is easy to spread through droplets and contacts in close proximity with the infected persons [4], [5]. Therefore, the attempts to break the transmission chain become important. Several of those are wearing faces masks, washing hands, and physical distancing. Nevertheless, the success of those attempts relies heavily on the people's responses to the COVID-19 pandemic [6]. Several studies have shown that wearing faces masks, washing hands, and physical distancing can prevent COVID-19 virus transmission [5], [7], [8] and are the main adaptive behaviors recommended to prevent the spread of infections [9], [10].

COVID-19 was declared as a pandemic in March 2020 by WHO and health emergency response was announced in all countries [3], sending several countries into lockdown to suppress the spread of the infection. As a response, Indonesia implemented Large Scale Social Restrictions (Pembatasan Sosial Berskala Besar/PSBB) in areas with high cases as a means of suppressing the spread of the infection [11]. It was followed then by implementing new normal life (NNL) policies. However, implementing a new normal life is not 
easy because people have to be ready for and obey $3 \mathrm{M}$ health protocols, which stand for menggunakan masker (mask-wearing), mencuci tangan (hand washing), and menjaga jarak (physical distancing) to break the transmission chain. Hence, several factors influence behavioral readiness.

Theory of planned behavior, which is the extension of the Theory of Reasoned Action, can be used to predict the intention of a person or group to be involved in behaving. A behavioral intention was influenced by an attitude towards a certain behavior that provideed expected results and benefits [12], [13]; and the knowledge of the behavior. An intention can predict both temporary and almost permanent behavioral readiness [14]. Therefore, an intervention is required so that people can be ready to implement a new normal life.

Furthermore, people's attitudes towards wearing face masks and washing hands were related to knowledge, gender, education, and income factors [15], [16]. Knowledge was significantly related to positive attitudes on the practice of COVID-19 prevention. Moreover, income was an important factor in developing an intention and behavioral readiness [12]. People with a high social-economic level, especially women, had good knowledge about, optimism for, and practice of COVID19 [17], [18]. Women tended to consider COVID-19 as a serious health issue, agree with the policy of restricting public activities, and obey the rules [6].

Therefore, this study aims at analyzing factors influencing people's attitudes towards wearing face masks and washing hands. The results of the research can be new evidence for the government and other related units to design interventions so that people can have the readiness to wear face masks and wash their hands.

\section{Materials and Methods}

\section{Study design}

The cross-sectional survey design was used to answer the research purposes. Survey is considered to be the right approach because it allows a big population to be assessed relatively easily [19]. The respondents were selected randomly, involving adults aged $>18$ years old in Jakarta, West Java, and Banten. The dependent variables are the attitude towards wearing face masks and washing hands. The independent variables are gender, age, education, job, knowledge, and comorbidity.

\section{Data collection techniques, tools, and procedures}

The information collected covers five main themes, namely (1) demographic data covering age, gender, education level, and employment status; (2) knowledge of COVID-19 and implementation of health protocols; (3) attitudes toward the use of masks; (4) attitude towards handwashing; and 5) the presence of comorbidities. A questionnaire was developed to assess knowledge about the definition of COVID-19, its causes, modes of transmission, and ways of prevention by implementing health protocols. This survey consists of 25 questions with five answer choices. When respondents choose the correct answer, they will be awarded 1 point and 0 points if they choose the wrong one. The highest score was 25 and the lowest was 0 . Attitude was measured by a questionnaire using a Likert scale of 1-5 with seven question items for each attitude towards wearing masks and washing hands. Before the questionnaire was used, validity and reliability tests were conducted to determine the accuracy and consistency of the questionnaire. The internal consistency of the questionnaire was controlled by using validity and reliability tests to obtain a certain Cronbach's alpha value. The knowledge questionnaire has a Cronbach alpha value of 0.75 , attitudes towards hand washing a score of 0.86 , and wearing a face mask a score of 0.78 . Data collection were collected online using a Google Form distributed through social media groups (WhatsApp). Of the 413 respondents, only 400 met the requirements of the analysis stage.

\section{Data processing and analysis}

The data were analyzed using SPSS program version 20. The descriptive analysis presents the frequency and percentage for categorical data, followed by bivariate and multivariate analysis. Bivariate analysis with simple logistic regression was performed to select the independent variables to be included in the multivariate analysis for modeling, which are variables with a significance level of 0.25 . Multivariate analysis used multiple logistic regression with a statistical significance level set at $p<0.05$. A test on the possibility of coordinating and interaction variables was also conducted.

\section{Results}

\section{Respondents' demographic characteristics}

From a total of 400 respondents who participated in this research, $26 \%$ were male and $74 \%$ were female; $75 \%$ were aged $18-35$; and $70.5 \%$ were workers with non-fixed income. Other demographic data are presented in Table 1.

\section{People attitudes towards wearing face masks and washing hands}

The proportion of respondents who had positive attitudes towards wearing face masks and 
Table 1: Respondents' demographic characteristics

\begin{tabular}{|c|c|c|c|c|c|c|c|c|c|c|c|}
\hline \multirow[t]{3}{*}{ NO } & \multirow[t]{3}{*}{ Variable } & \multicolumn{5}{|c|}{ Attitudes towards washing hands $(n=400)$} & \multicolumn{5}{|c|}{ Attitudes towards wearing face masks $(n=400)$} \\
\hline & & \multicolumn{2}{|c|}{ Positive } & \multicolumn{2}{|c|}{ Negative } & \multirow[t]{2}{*}{ Total } & \multicolumn{2}{|c|}{ Positive } & \multicolumn{2}{|c|}{ Negative } & \multirow[t]{2}{*}{ Total } \\
\hline & & $\mathrm{n}$ & $\%$ & $\mathrm{n}$ & $\%$ & & $\mathrm{n}$ & $\%$ & $\mathrm{n}$ & $\%$ & \\
\hline \multirow[t]{3}{*}{1} & Gender & & & & & & & & & & \\
\hline & Male & 54 & 13.50 & 50 & 12.50 & 104 & 49 & 12.25 & 55 & 13.75 & 104 \\
\hline & Female & 183 & 45.75 & 113 & 28.25 & 296 & 168 & 42.00 & 128 & 32.00 & 296 \\
\hline \multirow[t]{4}{*}{2} & Age-group & & & & & & & & & & \\
\hline & $18-35$ & 171 & 42.75 & 127 & 31.75 & 298 & 160 & 40.00 & 140 & 35.00 & 300 \\
\hline & $36-45$ & 51 & 12.75 & 31 & 7.75 & 82 & 43 & 10.75 & 37 & 9.25 & 80 \\
\hline & $\geq 46$ & 16 & 4.00 & 4 & 1.00 & 20 & 15 & 3.75 & 5 & 1.25 & 20 \\
\hline \multirow[t]{3}{*}{3} & Job status & & & & & & & & & & \\
\hline & Informal & 64 & 16.00 & 54 & 13.50 & 118 & 148 & 37.00 & 134 & 33.50 & 282 \\
\hline & Formal & 138 & 34.50 & 144 & 36.00 & 282 & 69 & 17.25 & 49 & 12.25 & 118 \\
\hline \multirow[t]{3}{*}{4} & Education level & & & & & & & & & & \\
\hline & Primary-Secondary & 57 & 14.25 & 60 & 15.00 & 117 & 61 & 15.25 & 56 & 14.00 & 117 \\
\hline & Higher & 145 & 36.25 & 138 & 34.50 & 283 & 156 & 39.00 & 127 & 31.75 & 283 \\
\hline \multirow[t]{3}{*}{5} & The existence of comorbidity & & & & & & & & & & \\
\hline & Yes & 36 & 9.00 & 2 & 0.50 & 38 & 20 & 5.00 & 18 & 4.50 & 38 \\
\hline & No & 185 & 46.25 & 177 & 44.25 & 362 & 197 & 49.25 & 165 & 41.25 & 362 \\
\hline \multirow[t]{4}{*}{6} & Knowledge & & & & & & & & & & \\
\hline & Enough & 6 & 1.50 & 7 & 1.75 & 13 & 6 & 1.50 & 9 & 2.25 & 15 \\
\hline & Good & 40 & 10.00 & 36 & 9.00 & 76 & 44 & 11.00 & 32 & 8.00 & 76 \\
\hline & Very good & 191 & 47.75 & 120 & 30.00 & 311 & 167 & 41.75 & 142 & 35.50 & 309 \\
\hline
\end{tabular}

washing hands was 54.3 against 59.3. The proportion of positive attitude on washing hands was bigger. The details are presented in Figure 1.

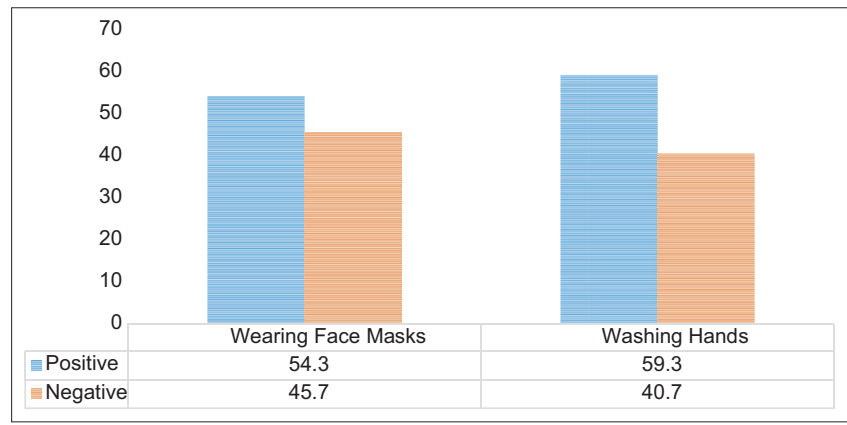

Figure 1: The proportion of people attitudes towards wearing face masks and washing hands

\section{Factors affecting the attitudes towards} wearing face masks

From the variable selection using simple logistic regression, the following variables with a value of $p<0.250$ were obtained. The results are shown in Table 2.

Table 2: Bivariate analysis results

\begin{tabular}{lll}
\hline N0 & Variabel Independent & $\mathrm{p}^{*}$ \\
\hline 1 & Gender & 0.09 \\
2 & Job status & 0.273 \\
3 & The existence of comorbidity & 0.833 \\
4 & Age group & 0.06 \\
5 & Education level & 0.580 \\
6 & Knowledge & 0.107 \\
\hline
\end{tabular}

The results of the multivariate analysis showing people's attitudes variable towards wearing face masks are presented in Table 3.

Independent variables influencing respondents' attitudes toward wearing face masks were age group and knowledge as the confounding variables. Respondents aged 36-45 years old could behave positively in wearing face masks 3.9 times bigger than respondents aged 18-35 years old with a score of $p=0.038$. Moreover, respondents aged $\geq 46$ years old could behave positively in wearing face masks 4.1 bigger than respondents aged $18-35$ years old with a score of $p=0.039$.

Table 3: Factors influencing people's attitudes towards wearing face masks

\begin{tabular}{|c|c|c|c|c|c|c|c|}
\hline \multirow[t]{2}{*}{ Variable } & \multirow[t]{2}{*}{ B } & \multirow[t]{2}{*}{ S.E. } & \multirow[t]{2}{*}{ Wald } & \multirow[t]{2}{*}{ Sig. } & \multirow[t]{2}{*}{$\operatorname{Exp}(\mathrm{B})$} & \multicolumn{2}{|c|}{$\begin{array}{l}95 \% \text { C.I. for } \\
\operatorname{EXP}(\mathrm{B})\end{array}$} \\
\hline & & & & & & Lower & Upper \\
\hline Age & & & 4.455 & 0.108 & & & \\
\hline Age (1) & 1.362 & 0.657 & 4.299 & 0.038 & 3.905 & 1.077 & 14.151 \\
\hline Age (2) & 1.422 & 0.690 & 4.253 & 0.039 & 4.145 & 1.073 & 16.012 \\
\hline Knowledge $^{*}$ & & & 17.558 & 0.618 & 1.470 & 0.323 & 6.689 \\
\hline Constant & 1.354 & 0.748 & 3.275 & 0.070 & 0.258 & & \\
\hline
\end{tabular}

\section{Factors influencing people's attitudes} towards washing hands

The bivariate analysis resulted in several independent variables that were included in the multivariate modeling analysis, which is shown in Table 4.

Table 4: Bivariate analysis results

\begin{tabular}{lll}
\hline N0 & Variabel independent & $\mathrm{p}^{*}$ \\
\hline 1 & Gender & 0.078 \\
2 & Job status & 0.175 \\
3 & the existence of comorbidity & 0.384 \\
4 & Age group & 0.057 \\
5 & Education level & 0.038 \\
6 & Knowledge & 0.163 \\
\hline
\end{tabular}

Gender, job types, age group, and education and knowledge level variables had a $p$ score of $\leq 0.250$, which was included in the multivariate model. The analysis results showed the variables that influenced respondents' attitudes towards washing hands, which are presented in Table 5 below.

The multivariate analysis results showed that the variables having significant influence on attitudes towards washing hands were gender, age group, and knowledge as the confounding variable.

Female respondents had the opportunity to be positive in washing their hands 1.7 times compared to men with a score of $p=0.029$. Respondents aged 
36-45 years old had the opportunity to have a positive attitude in washing hands 5 times with a score of $p=0.037$. Respondents aged $\geq 46$ years old had the opportunity to have a positive attitude by 4.8 times with $p=0.050$ compared to those aged 18-35 years old.

Table 5: Factors influencing people's attitudes towards washing hands

\begin{tabular}{|c|c|c|c|c|c|c|c|}
\hline \multirow[t]{2}{*}{ Variable } & \multirow[t]{2}{*}{$B$} & \multirow[t]{2}{*}{ S.E. } & \multirow[t]{2}{*}{ Wald } & \multirow[t]{2}{*}{ Sig. } & \multirow[t]{2}{*}{$\operatorname{Exp}(\mathrm{B})$} & \multicolumn{2}{|c|}{$\begin{array}{l}95 \% \text { C.I. for } \\
\text { EXP (B) }\end{array}$} \\
\hline & & & & & & Lower & Upper \\
\hline Gender & 0.533 & 0.245 & 4.756 & 0.029 & 1.705 & 1.056 & 2.754 \\
\hline Age group (years) & & & 4.368 & 0.113 & & & \\
\hline Age (1) & 1.621 & 0.776 & 4.368 & 0.037 & 5.060 & 1.106 & 23.147 \\
\hline Age (2) & 1.575 & 0.805 & 3.829 & 0.050 & 4.832 & 0.998 & 23.401 \\
\hline Knowledge* & 0.300 & 0.773 & 0.151 & 0.698 & 1.350 & 0.296 & 6.148 \\
\hline Constant & -2.125 & 0.856 & 6.161 & 0.013 & 0.119 & & \\
\hline
\end{tabular}

percentage: 64.3 , Cox \& Snell R Square; 0.118 , Nagelkerke R Square: 0.160 .

\section{Discussion}

COVID-19isavirusinfection pandemicthataffects people's lives greatly. It does not only affect the health aspect but also the economy, social politics, and national security aspects. The health threats are not only related to infection of the body's biological system but also the social-psychological aspect of the people [20]. Scientists are trying to control COVID-19 infections, such as through vaccine discovery research, medicine development, and optimizing education on the implementation of health protocols in the community [21]. Public education is an important key to preventing the spread of infection by wearing face masks, washing hands, maintaining distance, avoiding contact with infected people, and maintaining body immunity with nutritious food and adequate physical exercise [10], [22], [23]. Wearing face masks and washing hands are two important instruments that must be applied by people to prevent the spread of COVID-19 infection. Moreover, the attitude that is built is an important part of people's intentions in wearing masks and washing hands [14], [24] and can predict behavioral readiness [12].

\section{Attitudes towards wearing face masks}

The proportion of people who had positive attitudes towards wearing face masks was $54.3 \%$ with $45.7 \%$ having negative attitudes. Age and knowledge factors influenced the respondents' attitudes on wearing face masks. Respondents aged $36-45$ and $\geq 46$ years old had more positive attitudes towards wearing face masks compared to respondents aged 18-35 years old. It is in accordance with previous research stating that positive attitudes towards wearing face masks were related to age [25]; awareness and attempts to prevent the virus infection increase as the age goes up [15]. Socially responsible actions taken by adults were more significant than they are on younger people because of knowledge, experience, and responsibility factors [26], [27]. Therefore, positive attitudes that occurred in respondents aged $\geq 36$ toward wearing face masks would increase the intention and readiness in wearing face masks. On the contrary, respondents aged 18-35 years old may have low intention in wearing face masks, causing a bad impact on preventing the spread of the virus. The group required family or mentor assistance at school. This research also shows that good knowledge about COVID-19 determined positive attitudes towards wearing face masks. This is in line with previous research that claims a person's knowledge can contribute to determining his choice to behave [26], knowledge can improve attitudes and skills in wearing face masks [28], [29]; improving knowledge specifically on early adulthood (18-35 years old) was important so that positive attitudes towards wearing face masks could be built.

\section{Attitudes towards washing hands}

The proportion of people who had positive attitudes towards washing hands was $59.3 \%$ with $40.7 \%$ having negative attitudes. Several variables affecting the attitudes were gender, age, and knowledge. Women had more positive attitudes towards washing hands compared to men. This result is in line with previous research stating that women tended to consider COVID-19 as a serious health issue, agree with the public policies, and obey them [6]. Male and younger age respondents had a low habit of washing hands and low awareness of the virus infection [12]. Men's negative attitudes toward washing hands became a factor that put them prone to COVID19 infection that could lead to a worse condition even death. This is in accordance with previous research stating that COVID-19 infection could have more effect on men because of their low immunity responses in addition to their masculine lifestyle including smoking, alcohol consumption, and lack of preventive acts such as wearing face masks and washing hands [30]. The immune response in men is lower than in women because of the $X$ chromosome that contains immunity gen with high density so that women were stronger and more adaptive in terms of the immune response [31]. Comorbidity in men such as heart disease, hypertension, and diabetes mellitus also added to the factors. Similar with wearing face masks, the age group of $36-45$ years and $\geq 46$ years old had more positive attitudes toward washing hands compared to the age group of 18-35 years old.

Moreover, the knowledge factor also influenced the attitudes towards washing hands. Good knowledge was related to people's positive attitudes. This had implications for the importance of increasing public knowledge about COVID-19 and efforts to prevent its spread. This is in line with previous study on COVID19 knowledge, attitudes, and practices which showed that a COVID-19 knowledge score was significantly associated with a lower likelihood of negative attitudes and preventive practices towards COVID-19 [17]. 
health

\section{Research results implication on public}

By considering global data where COVID-19 infection was mostly suffered by men with a significant level of severity and death caused by negative attitudes towards health protocol compared to women, hence, it is appropriate that education and health promotion efforts in the community are more directed at men and the early adult age group (18-35 years old). Good knowledge about COVID-19 and its prevention need to be maintained because this factor is a reinforcement for attitude building. Positive attitudes and knowledge strengthening can be done through education and promotion to the community by empowering youth organizations in the community such as youth organizations, mosques, and schools/campuses.

\section{Conclusion}

Attitudes towards wearing masks and washing hands are important in building intentions and readiness to have new habits in preventing the spread of COVID-19. Positive attitudes towards wearing masks are influenced by age and knowledge with the addition of the influence of gender on attitudes towards washing hands. Women can be positive in washing their hands. The older the age the more chances there is to have a positive attitude towards wearing face masks and washing hands. Knowledge is an important variable in strengthening positive attitudes towards wearing face masks and washing hands. It is recommended to the government and related parties in handling COVID-19 in Indonesia to improve the Health Education program to increase public knowledge about COVID-19 and its prevention because knowledge is important in building positive attitudes in using masks and washing hands.

\section{Acknowledgments}

The authors would like to thank the Director of Poltekkes Bandung and the Chairperson of the Department of Nursing for the support in this research.

\section{Ethical Considerations}

This research was approved by the Research Ethics Committee of Jenderal A. Yani Institute of Health Science with No. 030/KEPK/VI/2020.
All respondents have received an explanation of the aims and objectives of the research and agreed to participate as research respondents.

\section{References}

1. World Health Organization. Novel Coronavirus (COVID-19) Situation. Geneva: World Health Organization; 2020. Available from: https://www.who [Last accessed on 2020 Jun 11].

2. Nuraini, R. Kasus Covid-19 Pertama, Masyarakat Jangan Panik Indonesia Portal Informasi Indonesia; 2020. Available from: https://indonesia.go.id/narasi/indonesia-dalam-angka/ekonomi/ kasus-covid-19-pertama-masyarakat-jangan-panik [Last accessed on 2020 Aug 25].

3. World Health Organization. Shortage of Personal Protective Equipment Endangering Health Workers Worldwide. Geneva: World Health Organization; 2020. Available from: https://www. who int/news.room/detail/03-03-2020-shortage of personalprotective-equipment-endangering-health-workers-worldwide [Last accessed on 2020 May 10]

4. Shereen MA, Khan S, Kazmi A, Bashir N, Siddique R. COVID19 infection: Origin, transmission, and characteristics of human coronaviruses. J Adv Res. 2020;24:91-8. https://doi. org/10.1016/j.jare.2020.03.005

PMid:32257431

5. Liang M, Gao L, Cheng C, Zhou Q, Uy JP, Heiner K, et al. Efficacy of face mask in preventing respiratory virus transmission: A systematic review and meta-analysis. Travel Med Infect Dis. 2020;36:101751. https://doi.org/10.1016/j.tmaid.2020.101751 PMid:32473312

6. Galasso V, Pons V, Profeta P, Becher M, Brouard S Foucault M. Gender differences in COVID-19 attitudes and behavior: Panel evidence from eight countries. Proc Natl Acad Sci U S Am. 2020;117(44):27285-1. https://doi.org/10.1073/ pnas. 2012520117

PMid:33060298

7. West R, Michie S, Rubin J, Amlôt R. Applying principles of behavior change to reduce SARS-CoV-2 transmission. Nat Hum Behav. 2020;4:451-9. https://doi.org/10.1038/ s41562-020-0887-9

8. Głabska D, Skolmowska D, Guzek D. Population-based study of the influence of the COVID-19 pandemic on hand hygiene behaviors-polish adolescents' COVID-19 experience (place-19) study. Sustainability (Switzerland). 2020;12(12):1011. https:// doi.org/10.3390/SU12124930

PMid:33271861

9. Zareipour MA, Ardakani MF, Moradali MR, Jadgal MS Movahed E. Determinants of COVID-19 prevention behavior in the elderly in urmia: Application of health belief model. Open Access Maced J Med Sci. 2020;8(T1):646-650. https://doi. org/10.3889/oamjms.2020.5653

10. Kemenkes RI. Guidelines for the Prevention and Contrpl of Corona Virus Disease (COVID-19) (Pedoman Pencegahan Pengendalian Coronavirus Disease (Covid-19). Edisi Revisi Ke-4 Maret 2020. Kemenkes RI, Direktorat Jenderal Pencegahan dan Pengendalian Penyakit; 2020. Available from: https://covid19.kemkes.go.id/protokol-covid-19/kmk-nohk-01-07-menkes-413-2020-ttg-pedoman-pencegahan-danpengendalian-covid-19 [Last accessed on 2020 Jul 12].

11. Permenkes. Regulation of the Minister of Health of the Republic of Indonesia Guidelines for Large-scale Social Limitation in the Context of Accelerating Handling of Corona Virus Disease 2019 
(Peraturan Menteri Kesehatan Republik Indonesia Pedoman Pembatasan Bersakala Besar dalam Rangka Percepatan Penanganan Corona Virus Disease 19),"Kementerian Kesehatan; 2020. Available from: https://covid19.go.id/p/ regulasi/permenkes-no-9-tahun-2020-tentang-pedomanpsbb-dalam-rangka-percepatan-penanganan-covid-19 [Last accessed on 2020 Jun 15].

12. Clemens KS, Matkovic J, Faasse K, Geers AL. The role of attitudes, affect, and income in predicting COVID-19 behavioral intentions. Front Psychol. 2021;11:567397. https://doi. org/10.3389/fpsyg.2020.567397

13. Wang J, Liu W, Zhao Q, Xiao M, Peng D. An application of the theory of planned behavior to predict the intention and practice of nursing staff toward physical restraint use in longterm care facilities: Structural equation modeling. Psychol Res Behav Manag. 2021;14:275-87. https://doi.org/10.2147/PRBM. S293759

PMid:33688280

14. Prasetyo YT, Castillo AM, Salonga LJ, Sia JA, Seneta JA. Factors affecting perceived effectiveness of COVID-19 prevention measures among filipinos during enhanced community quarantine in Luzon, Philippines: Integrating Protection motivation theory and extended theory of planned behavior Int J Infect Dis. 2020;99:312-23. https://doi.org/10.1016/j. ijid.2020.07.074

PMid:32768695

15. Hogan C, Atta M, Anderson P, Stead T, Solomon M, Banerjee P, et al. Knowledge and attitudes of us adults regarding COVID19. Int J Emerg Med. 2020;13(1):53. https://doi.org/10.1186/ s12245-020-00309-6

PMid:33138768

16. Czeisler MÉ, Garcia-Williams AG, Molinari NA, Gharpure R, Li Y, Barrett CE, et al. Demographic characteristics, experiences, and beliefs associated with hand hygiene among adults during the COVID-19 pandemic United States, June 24-30, 2020. MMWR Morbidity Mortality Weekly Report. 2020;69(41):148591. https://doi.org/10.15585/mmwr.mm6941a3

17. Zhong BL, Luo W, Li HM, Zhang QQ, Liu XG, Li WT, et al. Knowledge, attitudes, and practices towards COVID-19 among chinese residents during the rapid rise period of the COVID-19 outbreak: A quick online cross-sectional survey. Int J Biol Sci. 2020;16(10):1745-52. https://doi.org/10.7150/ijbs.45221 PMid:32226294

18. Bwire GM. Coronavirus: Why men are more vulnerable to Covid-19 than women? SN Compr Clin Med. 2020;2(7):874-6. https://doi.org/10.1007/s42399-020-00341-w PMid:32838138

19. Azlan AA, Hamzah MR, Jen T, Id S, Hadi S, Id A, et al. Public knowledge, attitudes and practices towards COVID-19: A crosssectional study in Malaysia, 2020;15(5):e0233668. https://doi. org/10.1371/journal.pone. 0233668

PMid:32437434

20. Dubey S, Biswas P, Ghosh R, Chatterjee S, Dubey MJ, Chatterjee S, et al. Psychosocial impact of COVID-19. Diabetes Metab Syndr. 2020;14(5):779-88. https://doi.org/10.1016/j. dsx.2020.05.035

PMid:32526627
21. Sohrabi C, Alsafi Z, O'Neill N, Khan M, Kerwan A, Al-Jabir A, et al. World Health Organization declares global emergency: A review of the 2019 novel coronavirus (COVID-19). Int J Surg. 2020;76:71-6. https://doi.org/10.1016/j.ijsu.2020.02.034 PMid:32112977

22. Esmaeili H. Social attitudes of people towards adhering to health protocols to prevent Covid-19 infection. Biomed J Sci Tech Res. 2020;32(1):24742-6. https://doi.org/10.26717/ bjstr.2020.32.005205

23. Singhal $S$, Singhal $P$, Mittal A, Agarwal BK, Khatib $M$, Gaidhane A. COVID 19 pandemic; a review on understanding the mode of transmission and application of strategies to delay/stop transmission with special reference to India. Open Public Health J. 2021;14(1):140-4. https://doi. org/10.2174/1874944502114010140

24. Sussman R, Gifford R. Causality in the theory of planned behavior. Pers Soc Psychol Bull. 2019;45(6):920-33. https://doi. org/10.1177/0146167218801363 PMid:30264655

25. Sulistyawati S, Rokhmayanti R, Aji B, Wijayanti SP, Hastuti SK, Sukesi TW, et al. Knowledge, attitudes, practices and information needs during the covid-19 pandemic in indonesia. Risk Manag Healthc Policy. 2021;14:163-75. https://doi.org/10.2147/RMHP. S288579

PMid:33488129

26. Cauffman E, Steinberg L. (Im)maturity of judgment in adolescence: Why adolescents may be less culpable than adults. Behav Sci Law. 2020;18(6):741-60. https://doi. org/10.1002/bsl.416

PMid: 11180420

27. Icenogle G, Steinberg L, Duell N, Chein J, Chang L, Chaudhary N, et al. Adolescents' cognitive capacity reaches adult levels prior to their psychosocial maturity: Evidence for a "maturity gap" in a multinational, cross-sectional sample. Law Hum Behav. 2019;43(1):69-85. https://doi.org/10.1037//hb0000315 PMid:30762417

28. Tso RV, Cowling BJ. (n.d.). Importance of face masks for COVID-19: A call for effective public education. Clin Infect Dis. 2020;71(16):2195-8. https://doi.org/10.1093/cid/ciaa593 PMid:32614045

29. Reuben RC, Danladi MM, Dauda SA, Ejembi PE. Knowledge, attitudes and practices towards COVID-19: An epidemiological survey in North-Central Nigeria. J Community Health. 2021;46:457-70. https://doi.org/10.1007/s10900-020-00881-1

30. Baker $\mathrm{P}$, White A, Morgan R. Men's health: COVID19 pandemic highlights need for overdue policy action. Lancet. 2020;395(10241):1886-8. http://dx.doi.org/10.1016/ S0140-6736(20)31303-9

PMid:32563357

31. Griffith DM, Sharma G, Holliday CS, Enyia OK, Valliere M, Semlow AR, et al. Men and COVID-19: A biopsychosocial approach to understanding sex differences in mortality and recommendations for practice and policy interventions. Prev Chronic Dis. 2020;17:E63. https://doi.org/10.5888/ PCD17.200247

PMid:32678061 